\title{
FAKTOR-FAKTOR YANG MEMPENGARUHI PENERAPAN KONSERVATISME AKUNTANSI PADA PERUSAHAAN MANUFAKTUR YANG TERDAFTAR DI BEI
}

\author{
Andreas Bambang Daryatno ${ }^{1}$, Linda Santioso ${ }^{2}$ \\ ${ }^{1}$ Jurusan Akuntansi, Universitas Tarumanagara \\ Email: andreasb@fe.untar.ac.id \\ 2 Jurusan Akuntansi, Universitas Tarumanagara \\ Email: lindas@fe.untar.ac.id
}

Masuk : 01-04-2020, revisi: 28-04-2020, diterima untuk diterbitkan : 28-04-2020

\begin{abstract}
ABSTRAK
Tujuan penelitian ini adalah untuk menguji secara empiris pengaruh risiko litigasi, ukuran perusahaan, struktur kepemilikan manajerial, intensitas modal, dan growth opportunities terhadap penerapan konservatisme akuntansi pada perusahaan manufaktur yang terdaftar di Bursa Efek Indonesia (BEI) selama periode tahun 2015-2017. Teknik pengambilan sampel dalam penelitian ini adalah metode purposive sampling. Penelitian dilakukan dengan total 33 sampel perusahaan manufaktur dari total populasi 136 perusahaan. Hasil dari penelitian ini adalah risiko litigasi, ukuran perusahaan, struktur kepemilikan manajerial, dan intensitas modal tidak berpengaruh terhadap penerapan konservatisme akuntansi. Growth opportunities memiliki pengaruh negatif terhadap penerapan konservatisme akuntansi. Penelitian ini menggunakan analisis regresi berganda. Alat analisis yang akan digunakan pada penelitian ini merupakan teknik analisis statistik yang berbasis software computer dengan menggunakan program Statistical Product and Service Solutions (SPSS) versi 23.
\end{abstract}

Kata Kunci: Risiko Litigasi, Ukuran Perusahaan, Struktur Kepemilikan Manajerial, Intensitas Modal, Growth Opportunities

\section{ABSTRACT}

The purpose of this study is to empirically examine the effect of litigation risk, company size, managerial ownership structure, capital intensity, and growth opportunities on the application of accounting conservatism to manufacturing companies listed on the Indonesia Stock Exchange (IDX) during the period 2015-2017. The sampling technique in this research is purposive sampling method. The study was conducted with a total of 33 samples of manufacturing companies from a total population of 136 companies. The results of this study are litigation risk, company size, managerial ownership structure, and capital intensity do not influence the application of accounting conservatism. Growth opportunities have a negative influence on the application of accounting conservatism. This research uses multiple regression analysis. The analytical tool that will be used in this research is a statistical analysis technique based on computer software using the Statistical Product and Service Solutions (SPSS) version 23 program.

Keywords: Litigation Risk, Firm Size, Structure Managerial Ownership, Capital Intensity, Growth Opportunities

\section{PENDAHULUAN}

Perusahaan merupakan suatu entitas bisnis dan terlibat dalam transaksi dengan banyak pihak, yang tentunya mempunyai risiko tinggi. Risiko bisnis yang tidak dapat dihindari tersebut dapat dikaitkan dengan peluang pertumbuhan di masa yang akan datang, seperti saat perusahaan memerlukan dana untuk pertumbuhan perusahaan yang dapat diperoleh baik dari pendanaan internal perusahaan (laba ditahan), ataupun dari pinjaman kepada pihak eksternal yang tentunya harus dapat dipertanggungjawabkan dengan menyampaikan informasi berupa laporan keuangan mengenai kinerja perusahaan. Laporan keuangan sebagai sumber informasi atas kinerja perusahaan harus disusun menurut prinsip-prinsip akuntansi yang berlaku dimana salah satu prinsip yang menjadi acuan dalam menyusun Laporan Keuangan adalah prinsip konservatisme akuntansi. Watts (2003, dalam Rizkyka, Nurhayati \& Fadilah, 2017) mengemukakan arti dari konservatisme akuntansi sebagai perilaku perusahaan untuk lebih hati-hati dalam menyampaikan laporan keuangannya dimana perusahaan cenderung untuk menunda dalam mengukur aktiva dan 
mengakui labanya, serta secepatnya mengakui kerugian perusahaan dan utang yang mempunyai kemungkinan akan terjadi. Hal ini menimbulkan permasalahan tersendiri karena berdasarkan kajian teori Jensen dan Meckling (1976) seperti Agency theory yang menunjukkan konflik kepentingan antara pemilik perusahaan atau pemegang saham (principal) dengan manajemen sebagai agent (Godfrey, et al., 2010). Konflik kepentingan ini disebut dengan agency problem (Ross, Westerfield, Jordan, 2010). Di sisi lain Positive Accounting Theory menjelaskan bahwa manajer akan cenderung memilih pilihan akuntansi yang akan meningkatkan kemakmuran mereka. (Watts and Zimmerman, 1986)

Menurut Chrisnoventie (2012, h.27) risiko litigasi sebagai "risiko yang melekat pada perusahaan yang memungkinkan akan mempengaruhi perilaku manajemen dalam penyusunan laporan keuangan. Dengan adanya risiko litigasi yang dihadapi perusahaan maka perilaku manajemen akan ikut terpengaruh. Juanda (2007, h.5) menyebutkan bahwa "tuntutan litigasi dapat timbul dari pihak kreditor, investor atau pihak lain yang berkepentingan dengan perusahaan". Apabila manajemen sebagai pengelola perusahaan tidak memenuhi kewajibannya kepada pihak investor, kreditor, dan pihak lain yang berkepentingan maka pihak-pihak tersebut memiliki kewenangan untuk menuntut haknya. Johnson et al. dan Qiang (dalam Juanda, 2007) menyebutkan bahwa apabila kepentingan investor dan kreditor tidak terpenuhi maka akan memicu timbulnya risiko litigasi. Ditinjau dari ukuran, Perusahaan yang memiliki ukuran besar, akan menjalankan kegiatan perusahaan dengan lebih rumit dan seringkali terjadi kurangnya pemantauan oleh manajer dan pengambilan keputusan yang tidak terpusat. Hal ini menurut Jensen (1993 dalam Boussaid, Hamza \& Sougne, 2015) mengakibatkan, manajer lebih memilih untuk tidak menyajikan laporan keuangan secara konservatif dan cenderung melakukan manipulasi agar perusahaan terlihat lebih menguntungkan. Ditinjau dari Struktur kepemilikan suatu perusahaan juga bisa mempengaruhi manajemen untuk menyusun laporan keuangan secara konservatif. Wardhani (2008, dalam Oktomegah, 2012) menyebutkan bahwa perusahaan yang memiliki struktur kepemilikan didominasi oleh manajer, maka manajer akan semakin berupaya dalam meningkatkan nilai perusahaan tersebut.

Menurut Sinarti dan Mutihatunnisa (2015), intensitas modal dalam suatu perusahaan menunjukkan banyaknya aset yang dibutuhkan perusahaan yang bersangkutan agar dapat menghasilkan pendapatan. Intensitas modal adalah suatu gambaran seberapa besar modal suatu perusahaan dinyatakan dalam bentuk aset (Raharjo dan Dewi, 2016). Menurut Purnama dan Daljono (2013) perusahaan dapat dibedakan menjadi perusahaan yang padat karya atau padat modal. Perusahaan yang padat modal memiliki sumber daya yang memadai dalam menghasilkan penjualan. Disini intensitas modal dalam perusahaan berhubungan dengan biaya politis, dimana perusahaan dengan intensitas modal yang tinggi atau padat modal dihipotesiskan memiliki biaya politik yang cenderung besar, dan mungkin lebih memilih melaporkan Laporan Keuangan yang cenderung konservatif.

Perusahaan hendaknya selalu ingin bertumbuh dan memperluas operasinya. Dalam Fatmariani (2013), growth opportunities dinyatakan sebagai kesempatan atau peluang bagi suatu perusahaan dalam berinvestasi pada hal-hal yang dapat mendatangkan keuntungan bagi perusahaan. Growth opportunities memiliki definisi sejauh mana suatu perusahaan berpeluang dalam mengalami pertumbuhan di masa mendatang, dan untuk mengalami peluang pertumbuhan yang baik membutuhkan dana yang relatif besar (Nuraini, 2017). Growth opportunities merupakan peluang perusahaan untuk meningkatkan jumlah investasi. Pada umumnya perusahaan yang tingkat pertumbuhannya tinggi lebih cenderung untuk melakukan minimalisasi laba. Widya (2004 dalam Dewi, Herawati \& Sinarwati, 2014) mengemukakan bahwa semakin tinggi tingkat pertumbuhan 
suatu perusahaan maka akan semakin tinggi juga kecenderungan perusahaan tersebut memilih akuntansi yang konservatif. Alfian dan Sabeni (2013) serta Quljanah, Nuraina, dan Wijaya (2017) menyatakan bahwa growth opportunities berpengaruh signifikan positif terhadap penerapan konservatisme akuntansi.

Berdasarkan penelitian dan kajian teori yang menunjukkan ketidakkonsistenan, maka akan dilakukan kajian secara empiris terkait faktor-faktor yang mempengaruhi Konservatisme Akuntansi. Penelitian ini dilakukan untuk membuktikan secara empiris pengaruh Risiko Litigasi, Ukuran Perusahaan, Struktur Kepemilikan Manajerial, Intensitas Modal, dan Growth Opportunities terhadap Konservatisme Akuntansi khususnya pada perusahaan manufaktur yang terdaftar di Bursa Efek Indonesia

\section{Rumusan Masalah}

$\mathrm{H}_{1}$ : Terdapat pengaruh negatif risiko litigasi terhadap penerapan konservatisme akuntansi.

$\mathrm{H}_{2}$ : Terdapat pengaruh negatif ukuran perusahaan terhadap penerapan konservatisme akuntansi.

$\mathrm{H}_{3}$ : Terdapat pengaruh positif struktur kepemilikan terhadap penerapan konservatisme akuntansi.

$\mathrm{H}_{4}$ : Terdapat pengaruh positif intensitas modal terhadap penerapan konservatisme akuntansi.

$\mathrm{H}_{5}$ : Terdapat pengaruh positif growth opportunities terhadap penerapan konservatisme akuntansi.

\section{Model Penelitian}

Model penelitian dalam penelitian ini seperti digambarkan dibawah ini

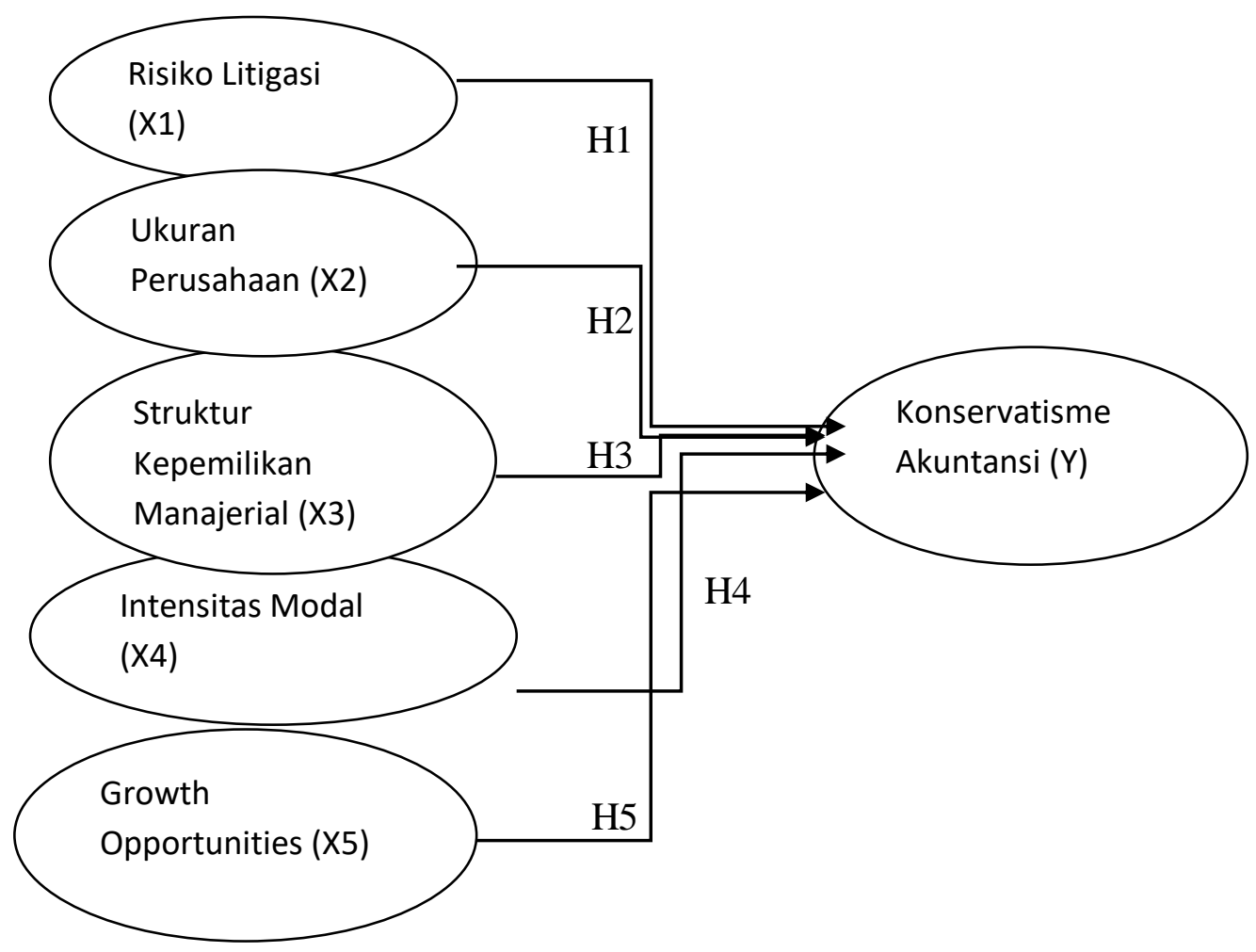

Gambar 1. Model Penelitian 


\section{METODE PENELITIAN}

\section{Populasi dan Obyek Penelitian}

Penelitian ini mempergunakan data sekunder. Populasi yang dipergunakan adalah total 136 perusahaan manufaktur yang terdapat di Bursa Efek Indonesia. Periode pengamatan dilakukan pada tahun 2015-2017. Sampel penelitian berjumlah 33 perusahaan.

\section{Metode Penarikan Sampel}

Metode pengambilan sampel dalam penelitian ini adalah nonprobability sampling dengan teknik pengambilan sampel purposive sampling. Purposive sampling merupakan teknik pengambilan sampel dengan menggunakan sejumlah pertimbangan khusus sehingga layak dipilih sebagai sampel (Sekaran dan Bougie, 2013). Berikut ini adalah kriteria pemilihan sampel:

1. Perusahaan manufaktur yang terdaftar di Bursa Efek Indonesia secara berturut-turut selama tahun 2015-2017.

2. Perusahaan manufaktur yang Laporan Keuangannya dalam mata uang rupiah.

3. Perusahaan manufaktur yang sebagian saham beredarnya selama tahun 2015-2017 secara berturut-turut dimiliki oleh pihak manajerial (direksi dan komisaris perusahaan).

4. Perusahaan manufaktur yang tidak mengalami kerugian usaha.

\section{Teknik Analisis}

Penelitian ini menggunakan analisis regresi berganda. Alat analisis yang akan digunakan merupakan teknik analisis statistik, yang merupakan teknik analisis berbasis software computer dengan menggunakan program Statistical Product and Service Solutions (SPSS) versi 23.

\section{Operasionalisasi Variabel Penelitian}

Variabel dependen yang digunakan adalah Konservatisme Akuntansi, sedangkan variabel independen yang dipergunakan adalah Risiko Litigasi, Ukuran Perusahaan, Struktur Kepemilikan Manajerial, Intensitas Modal, dan Growth Opportunities. Konservatisme akuntansi adalah suatu pilihan sejauh mana penyaji laporan keuangan memilih untuk melaporkan rugi dengan segera sedangkan laba ditangguhkan. Menurut Savitri (2016, h. 52), diadaptasi dari model Givoly dan Hayn, konservatisme dapat diukur dengan cara yaitu melihat perbedaan antara laba operasi sebelum depresiasi/amortisasi dan arus kas kegiatan operasi kemudian dibagi dengan total aset. Sehingga pengukuran konservatisme akuntansi dapat disimpulkan sebagai berikut:

$$
\text { CONACC }=\frac{(\mathrm{NIO}+\mathrm{DEP}-\mathrm{CFO}) \times(-1)}{\mathrm{TA}}
$$

Keterangan:

CONACC : Konservatisme akuntansi berdasarkan perhitungan akrual

NIO : Laba operasi (usaha) tahun berjalan

DEP : Beban penyusutan aset tetap dan beban amortisasi aset tak berwujud tahun berjalan

CFO : Arus kas dari aktivitas operasi selama tahun berjalan

TA : Total aset akhir periode

Risiko Litigasi adalah risiko yang terdapat pada perusahaan yang dapat menimbulkan kemungkinan terjadinya ancaman litigasi bagi perusahaan yang dilakukan oleh pihak-pihak yang terkait dengan perusahaan yang merasa dirugikan. Risiko potensial terjadinya litigasi dipicu oleh potensi yang melekat pada perusahaan berkaitan dengan tidak terpenuhinya kepentingan investor dan kreditor. Chrisnoventhie (2012) menghitung risiko litigasi dengan membagi total utang dengan total ekuitas 


$$
\text { Risiko Litigasi }=\quad \frac{\text { Total utang }}{\text { Total ekuitas }}
$$

Ukuran dari suatu perusahaan menunjukkan seberapa besar sumber daya yang dikuasai perusahaan. Ukuran perusahaan dapat diamati dari jumlah aset yang dimiliki oleh perusahaan dan dapat diukur dengan logaritma dari total aset (Susanto \& Ramadhani, 2016).

$$
\mathrm{SIZE}=\operatorname{Ln}(\text { total aset) }
$$

Struktur kepemilikan manajerial mengindikasikan seberapa besar saham perusahaan yang dimiliki oleh pihak manajerial, yakni jajaran direksi dan komisaris perusahaan bersangkutan. Struktur kepemilikan manajerial dalam suatu perusahaan dapat dihitung dengan cara membagi jumlah lembar saham yang dimiliki pihak manajerial dengan jumlah lembar saham beredar perusahaan (Alkurdi, Nimer \& Dabaghia, 2017).

$$
\mathrm{SKM}=\frac{\text { jumlah lembar saham pihak manajerial }}{\text { jumlah saham beredar }}
$$

Intensitas modal adalah gambaran mengenai seberapa banyak modal perusahaan (dalam hal ini ditunjukkan dari aset perusahaan) yang dibutuhkan untuk memperoleh pendapatan (Purnama \& Daljono, 2013 dalam Susanto \& Ramadhani, 2016). Oleh karena itu, menurut Susanto dan Ramadhani (2016), intensitas modal suatu perusahaan dapat diukur dengan membagi total aset dengan total pendapatan (penjualan) selama tahun berjalan.

$$
\text { Intensitas Modal/Capital Intensity }(\mathrm{CI})=\frac{\text { total aset }}{\text { total penjualan }}
$$

Growth Opportunities adalah suatu cara untuk menentukan seberapa besar kesempatan perusahaan dalam mengalami pertumbuhan. Berdasarkan rumus Collins dan Kothari (1989) dalam Susanto dan Ramadhani (2016), growth opportunities diproksikan dengan rumus Market to Book Value of Equity (MBV). Market to Book Value of Equity (MBV) dapat dirumuskan sebagai berikut:

$$
\begin{aligned}
& \text { Growth Opportunities }(\mathrm{MBV})= \\
& \text { Jumlah saham beredar } \times \text { harga penutupan saham }
\end{aligned}
$$

\section{Total Ekuitas}

\section{Metode Analisis Data}

1. Pengujian Asumsi Klasik :

(a) Normalitas

(b) Multikolinieritas

(c) Heteroskedastisitas

(d) Autokorelasi

2. Statistik Deskriptif

3. Analisis Regresi Berganda

Berikut adalah model regresi linier berganda yang dipergunakan :

$$
\text { CONACC }=\mathrm{a}+\beta_{1} L E V+\beta_{2} S I Z E+\beta_{3} \mathrm{SKM}+\beta_{4} C I+\beta_{5} M B V+\varepsilon
$$

Keterangan :

CONACC : konservatisme akuntansi

a

: konstanta 


$\begin{array}{ll}\beta_{1}-\beta_{5} & : \text { koefisien regresi } \\ \text { LIR } & : \text { Risiko Litigasi } \\ \text { SIZE } & : \text { ukuran perusahaan } \\ \text { SKM } & : \text { struktur kepemilikan manajerial } \\ C I & : \text { intensitas modal } \\ M B V & : \text { growth opportunities } \\ \varepsilon & : \text { error }\end{array}$

\section{A. Teknik Pengujian Hipotesis}

Hipotesis akan diuji dengan uji simultan (uji statistik F), uji koefisien korelasi (R), uji koefisien determinasi $\left(\mathrm{R}^{2}\right)$, dan uji signifikan secara parsial (uji statistik t). Taraf signifikansi yang dipergunakan adalah sebesar $5 \%$.

Dalam Uji F akan diuji kelayakan (fit) tidaknya suatu model regresi linear berganda yang digunakan dan apakah semua variable independen yang dipergunakan dalam model dapat berpengaruh secara simultan terhadap variable dependen. (Ghozali 2016:198). Jika nilai signifikansi di tabel ANOVA pada SPSS kurang dari 0,05, dapat dikatakan bahwa model regresi yang dipergunakan layak (fit) dan secara simultan variabel dependen dapat dipengaruhi secara signifikan oleh variable independen.

Uji Koefisien Korelasi Ganda (R) untuk menguji seberapa besar keeratan hubungan variable independen terhadap variable dependen. Menurut Priyatno (2013) koefisien korelasi ganda yaitu korelasi antara dua atau lebih variable independen terhadap variable dependen. Nilai R terletak di antara $0-1$, jika mendekati 1 maka hubungan yang terjadi semakin kuat, tetapi jika mendekati 0 hubungan yang terjadi semakin lemah.

Uji Koefisien Determinasi $\left(\mathrm{R}^{2}\right)$ untuk menguji seberapa besar variasi variable dependen dapat diterangkan oleh variable-variable independen. Semakin tinggi nilai $\mathrm{R}^{2}$ dan hampir mendekati satu berarti variasi variabel dependen yang terjadi dapat dijelaskan oleh hampir semua informasi yang diberikan oleh variabel independen. Akan tetapi terdapat pula kelemahan dari koefisien determinasi yaitu setiap ada penambahan satu variable independen, akan meningkatkan nilai $\mathrm{R}^{2}$ walaupun variable independen yang dimasukkan tersebut belum tentu mempengaruhi atau tidak mempunyai pengaruh terhadap variable dependen.

Oleh karena itu digunakan Adjusted $\mathrm{R}^{2}$ untuk mengukur koefisien determinasi. (Ghozali, 2016)

Menurut Ghozali (2016:98), untuk menguji apakah suatu variable dependen dapat dipengaruhi oleh variable independen secara parsial dapat digunakan uji t. Jika nilai t hitung lebih besar dari nilai t tabel, dan nilai signifikan pada tabel output SPSS dibawah 0,05, maka dapat dikatakan bahwa variable dependen secara parsial dipengaruhi oleh variable independen.

\section{HASIL DAN PEMBAHASAN}

\section{Hasil Uji Statistik}

Hasil uji asumsi klasik menunjukkan hasil yang baik yang dibuktikan dengan keseluruhan variabel yang lolos uji asumsi klasik. Ketika dilakukan pengujian normalitas, autokorelasi dan multikolinieritas, seluruh variabel lolos uji sehingga model regresi, variabel pengganggu atau residual terdistribusi secara normal, tidak adanya kemiripan antar variabel independen dalam model, tidak adanya penyimpangan korelasi yang terjadi antara residual pada satu pengamatan dengan pengamatan lain pada model regresi serta variasi residual absolut berbeda untuk semua pengamatan pada model regresi. 
Persamaan model regresi yang dihasilkan adalah sebagai berikut :

CONACC $=-0,102-0,002 L I R+0,002 S I Z E+0,071$ SKM $+0,005 C I-0,009 M B V+\varepsilon$

Hasil uji t untuk setiap variabel dapat dilihat pada tabel di bawah ini.

Tabel 5.1

Hasil Pengujian Parsial (Uji t)

Coefficients $^{\mathbf{a}}$

\begin{tabular}{|c|c|c|c|c|c|c|}
\hline \multirow{2}{*}{\multicolumn{2}{|c|}{ Model }} & \multicolumn{2}{|c|}{ Unstandardized Coefficients } & \multirow{2}{*}{$\begin{array}{l}\text { Standardized } \\
\text { Coefficients } \\
\text { Beta }\end{array}$} & \multirow[b]{2}{*}{$\mathrm{T}$} & \multirow[b]{2}{*}{ Sig. } \\
\hline & & $\mathrm{B}$ & Std. Error & & & \\
\hline \multirow[t]{6}{*}{1} & (Constant) & -.102 & .099 & & -1.032 & .305 \\
\hline & LIR & -.002 & .009 & -.025 & -.250 & .803 \\
\hline & SIZE & .002 & .003 & .067 & .595 & .553 \\
\hline & SKM & .071 & .046 & .163 & 1.536 & .128 \\
\hline & CI & .005 & .009 & .066 & .616 & .539 \\
\hline & MBV & -.009 & .004 & -.255 & -2.271 & .025 \\
\hline
\end{tabular}

a. Dependent Variable: CONACC

Hasil pengujian statistik t untuk mengetahui pengaruh masing-masing variabel independen terhadap variabel dependen dapat dilihat dari kolom sig. yang menandakan nilai signifikansi. Dari nilai signifikansi variabel-variabel independen yang ada dalam tabel di atas dapat ditunjukkan bahwa:

a. Besarnya nilai t dari variabel risiko litigasi (LIR) adalah -0,250 dan nilai koefisiennya adalah -0,002. Nilai signifikansi dari variabel independen variabel risiko litigasi (LIR) adalah senilai 0,803 . Nilai 0,803 lebih besar dari nilai $0,05(0,803>0,05)$ artinya adalah variabel risiko litigasi (LIR) tidak memiliki pengaruh secara parsial terhadap variabel dependen konservatisme akuntansi (CONACC), maka dari itu hipotesis penelitian (H1) yang telah ditetapkan sebelumnya mengenai pengaruh variabel risiko litigasi (LIR) terhadap variabel konservatisme akuntansi (CONACC) tidak diterima atau ditolak.

b. Nilai $\mathrm{t}$ dan nilai koefisien untuk variabel ukuran perusahaan (SIZE) masing-masing menunjukkan angka 0,595 dan 0,002. Variabel ukuran perusahaan (SIZE) menunjukkan nilai signifikansi sebesar 0,553. Berdasarkan kriteria di atas dapat diartikan bahwa variabel ukuran perusahaan (SIZE) tidak berpengaruh secara parsial pada variabel konservatisme akuntansi (CONACC) dikarenakan nilai 0,553 lebih besar dibandingkan dengan 0,05 $(0,553>0,05)$. Oleh karena itu, hipotesis penelitian $(\mathrm{H} 2)$ yang menguraikan pengaruh variabel ukuran perusahaan (SIZE) terhadap penerapan konservatisme akuntansi (CONACC) ditolak atau tidak diterima.

c. Untuk variabel independen selanjutnya yaitu variabel struktur kepemilikan manajerial (SKM), dari tabel 5.1 diperoleh nilai signifikan 0,128 , nilai t sebesar 1,536 dan nilai koefisiennya adalah senilai 0,071. Nilai tersebut menunjukkan bahwa nilai signifikan variabel struktur kepemilikan manajerial $(\mathrm{SKM})$ lebih besar dari 0,05 $(0,071>0,05)$ dan artinya variabel struktur kepemilikan manajerial (SKM) tidak dapat mempengaruhi variabel konservatisme akuntansi (CONACC) secara parsial. Hipotesis penelitian (H3) atas pengaruh variabel struktur kepemilikan manajerial (SKM) terhadap tingkat penerapan konservatisme akuntansi (CONACC) yang telah ditetapkan dengan ini ditolak atau tidak diterima.

d. Variabel intensitas modal (CI) memiliki nilai t sebesar 0,616, sedangkan nilai koefisiennya adalah 0,005 . Nilai signifikansi untuk variabel intensitas modal (CI) adalah senilai 0,539 yang lebih besar dari 0,05 $(0,539>0,05)$. Dari nilai signifikansi tersebut dapat disimpulkan 
bahwa variabel konservatisme akuntansi (CONACC) tidak dapat dipengaruhi secara parsial oleh variabel intensitas modal (CI). Dengan ini maka dapat disimpulkan bahwa hipotesis penelitian (H4) yang menguraikan tentang pengaruh intensitas modal (CI) terhadap konservatisme akuntansi (CONACC) tidak diterima atau ditolak.

e. Variabel independen growth opportunities (MBV) memiliki nilai t sebesar -2,271 dan nilai koefisiennya adalah sebesar -0,009. Nilai signifikansi dari variabel growth opportunities (MBV) adalah 0,025 oleh karena itu variabel growth opportunities (MBV) disimpulkan memiliki pengaruh negatif yang signifikan terhadap variabel konservatisme akuntansi (CONACC). Hal ini dapat dilihat melalui nilai signifikansi dari variabel growth opportunities sebesar 0,025 yang lebih kecil dibandingkan dengan 0,05 $(0,025<0,05)$. Hipotesis penelitian (H5) yang menyatakan pengaruh signifikan negatif variabel growth opportunities (MBV) terhadap konservatisme akuntansi (CONACC) diterima.

Hasil uji t di atas menyatakan bahwa variabel risiko litigasi, ukuran perusahaan, struktur kepemilikan manajerial, dan intensitas modal tidak mempunyai pengaruh signifikan terhadap variabel dependen secara parsial, sedangkan untuk variabel growth opportunities memiliki pengaruh negatif terhadap penerapan konservatisme akuntansi.

Untuk mengetahui korelasi variabel-variabel independen terhadap variabel dependen, maka dilakukan uji korelasi (R). Dalam penelitian ini menunjukkan nilai $\mathrm{R}$ sebesar 0.317 yang tergolong cukup. Uji Koefisien Determinasi (Adjusted $R^{2}$ ) yang digunakan untuk mengetahui persentase sumbangan variabel independen secara bersama-sama terhadap variabel dependen menunjukkan angka 0,052. Nilai tersebut menunjukkan bahwa besarnya variabel dependen dalam penelitian ini, yaitu konservatisme akuntansi dapat dijelaskan oleh variabel independennya sebesar 5,2\%, sisanya sebesar 94,8\% dijelaskan oleh variabel lain.

Uji statistik F atau uji ANOVA ini dimaksudkan untuk menguji kelayakan model regresi untuk digunakan. Selain itu, uji F ini juga dimaksudkan untuk melihat kemampuan variabel independen untuk dapat mempengaruhi variabel dependen secara simultan atau bersama-sama. Hasilnya adalah model regresi layak digunakan dan variabel independen secara bersama-sama dapat mempengaruhi variabel dependen secara signifikan yang ditunjukkan dengan hasil uji $\mathrm{F}$ sebesar 0,074 .

Berdasarkan hasil pengujian data dalam penelitian ini, penerapan konservatisme akuntansi pada perusahaan manufaktur yang terdaftar di Bursa Efek Indonesia periode 2015-2017 menunjukkan bahwa penerapan konservatisme akuntansi tidak dipengaruhi oleh risiko litigasi, ukuran perusahaan, struktur kepemilikan manajerial, dan intensitas modal, sedangkan konservatisme akuntansi dipengaruhi oleh growth opportunities secara negatif.

Hal ini dapat dikarenakan tingkat utang yang dimiliki perusahaan bukan satu-satunya hal yang dapat meningkatkan biaya politik, serta bukan acuan dalam menentukan besarnya risiko litigasi yang akan dihadapi perusahaan sebagai suatu entitas bisnis. Untuk ukuran perusahaan tidak memiliki pengaruh terhadap penerapan konservatisme akuntansi dapat disebabkan karena ukuran perusahaan (SIZE) yang diproksikan dengan logaritma natural total aset tidak terlalu dipertimbangkan oleh perusahaan untuk dapat menerapkan konservatisme akuntansi dalam pelaporan keuangannya. Struktur kepemilikan manajerial juga tidak berpengaruh terhadap konservatisme akuntansi mungkin disebabkan karena porsi kepemilikan saham perusahaan oleh komisaris dan direksi perusahaan untuk perusahaan manufaktur di Indonesia tahun 2015-2017 tidak terlalu signifikan karena secara rata-rata hanya meliputi kurang dari $20 \%$ atas kepemilikan 
saham perusahaan secara keseluruhan. Intensitas modal tidak memiliki pengaruh terhadap konservatisme akuntansi, hal ini terkait adanya suatu dugaan bahwa intensitas modal sebagai proksi biaya politis yang dapat terjadi karena perubahan peraturan dan regulasi yang berlaku dan dampaknya terhadap perusahaan serta tidak terkait langsung dengan aspek pendanaan atau permodalan perusahaan. Mengenai growth opportunities yang memiliki pengaruh negatif terhadap konservatisme akuntansi, hal ini dikarenakan perusahaan yang sedang bertumbuh membutuhkan dana yang lebih besar sehingga manajer perusahaan berusaha untuk melaporkan laporan keuangan yang menampilkan laba untuk memenuhi kebutuhan investasi. Dana untuk memenuhi kebutuhan investasi tersebut diharapkan didapatkan dari pihak eksternal sehingga perusahaan tidak menurunkan laba. Hal ini dilakukan agar investor tertarik melakukan investasi pada perusahaan yang bersangkutan karena memiliki kepercayaan bahwa perusahaan tersebut diyakini dapat memenuhi kewajiban dalam melunasi utang kepada investor tersebut. Alasan ini mendasari hasil penelitian yang menunjukkan bahwa adanya kesempatan tumbuh perusahaan berpengaruh secara negatif terhadap pemilihan prinsip akuntansi yang konservatif.

\section{KESIMPULAN DAN SARAN \\ Kesimpulan}

Terdapat 5 (Lima) simpulan dari hasil penelitian ini, yaitu:

1. Pertama, Risiko Litigasi tidak mempunyai pengaruh terhadap penerapan Konservatisme Akuntansi.

2. Kedua, Ukuran Perusahaan tidak mempunyai pengaruh terhadap penerapan Konservatisme Akuntansi.

3. Ketiga, Struktur Kepemilikan Manajerial tidak mempunyai pengaruh terhadap penerapan Konservatisme Akuntansi.

4. Keempat, Intensitas Modal tidak mempunyai pengaruh terhadap penerapan Konservatisme Akuntansi.

5. Kelima, Growth Opportunities mempunyai pengaruh negatif terhadap penerapan Konservatisme Akuntansi.

\section{Keterbatasan Penelitian}

1. Pertama, penelitian hanya dilakukan pada perusahaan dengan sektor manufaktur saja dan juga periode pengamatan hanya 3 (tiga) tahun yaitu dari tahun 2015-2017.

2. Kedua, jumlah sampel yang digunakan juga terbatas hanya mengambil 33 perusahaan manufaktur yang lolos dari kriteria penyeleksian sampel sehingga data yang digunakan untuk penelitian adalah sebanyak 99 buah data (terdiri dari 33 perusahaan selama 3 tahun).

3. Ketiga, variabel yang digunakan hanya 5 (lima) buah variabel independen untuk mengukur tingkat penerapan konservatisme akuntansi.

4. Keempat, pengukuran atas konservatisme akuntansi juga hanya menggunakan pengukuran secara akrual saja.

\section{Saran-Saran}

1. Pertama, untuk penelitian-penelitian berikutnya sebaiknya ruang lingkup penelitian mungkin dapat diperluas dengan misalnya menambah perusahaan di sektor lain selain manufaktur.

2. Kedua, penelitian juga dapat diperluas dalam lingkup periode pengamatan agar hasil penelitian dapat memperoleh hasil yang lebih baik lagi dan lebih dapat menjelaskan konservatisme akuntansi sebagai variabel dependen.

3. Ketiga, penelitian juga dapat dilakukan dengan memperluas variabel penelitian yang mungkin dapat mempengaruhi tingkat penerapan konservatisme akuntansi. 
4. Keempat, untuk pengukuran atas konservatisme akuntansi juga dapat diperluas atau mungkin dapat diukur dengan beberapa pengukuran lainnya selain pengukuran akrual sehingga dapat lebih memperjelas pengaruh variabel independen terhadap variabel dependen.

\section{REFERENSI}

Alfian A., \& Sabeni A. (2013). Analisis Faktor-faktor yang Berpengaruh terhadap Pemilihan Konservatisme Akuntansi. Diponegoro Journal of Accounting, 2(3), 1-10.

Alkurdi, A., Nimer, M. A., \& Dabaghia, M. (2017). Accounting Conservatism and Ownership Structure Effect: Evidence from Industrial and Financial Jordanian Listed Companies. International Journal of Economics and Financial Issues, 7(2), 608-619.

Boussaid, N., Hamza, T., \& Sougne, D. (2015). Corporate Board Attributes and Conditional Accounting Conservatism: Evidence from French Firms. The Journal of Applied Business Research, 31(3), 871-890.

Chrisnoventie, Diajeng. (2012). Pengaruh Ukuran KAP dan Spesialisasi Industri KAP terhadap Kualitas Audit:Tingkat Risiko Litigasi Perusahaan sebagai Variabel Moderasi. Jurnal FEB Universitas Diponegoro Semarang.

Dewi, L. P. K., Herawati, N. T., \& Sinarwati, N. K. (2014). Faktor-faktor yang Berpengaruh terhadap Konservatisme Akuntansi pada Perusahaan Manufaktur di BEI. Jurnal Akuntansi Program S1 Universitas Pendidikan Ganesha, 2(1), 1-12.

Fatmariani. (2013). Pengaruh Struktur Kepemilikan, Debt Covenant dan Growth Opportunities terhadap Konservatisme Akuntansi pada Perusahaan Manufaktur yang Terdaftar di Bursa Efek Indonesia. Jurnal Akuntansi, 1(1), 1-20.

Ghozali, Imam. (2016). Aplikasi analisis multivariate dengan program IBM SPSS 21. Edisi 7. Semarang: Universitas Diponegoro.

Godfrey, J., Allan, H., Anna, T., \& et al. (2010). Accounting Theory Seventh Edition. New York: Wiley \& Sons, Inc.

Jensen, M., \& Meckling, W. H. (1976). Theory of the firm: Managerial behavior, agency costs and ownership structure. Journal of Financial Economics, 3, 305-360.

Juanda, A. (2007). Pengaruh Risiko Litigasi dan Tipe Strategi terhadap Hubungan antara Konflik Kepentingan dan Konservatisme Akuntansi. Makalah Simposium Nasional Akuntansi X Universitas Hasanuddin Makassar.

Nuraini, I. (2017). Pengaruh Growth Opportunities, Leverage, dan Financial Distress terhadap Konservatisme Akuntansi pada Perusahaan Farmasi (Studi Empiris di Bursa Efek Indonesia Periode 2010-2015). Jurnal Akuntansi, 1(1), 1-18.

Oktomegah, C. (2012). Faktor-faktor yang Mempengaruhi Penerapan Konservatisme pada Perusahaan Manufaktur di BEI. Jurnal Ilmiah Mahasiswa Akuntansi, 1(1), 36-42.

Priyatno, Duwi. (2013). Analisis korelasi, Regresi, dan Multivariative dengan SPSS, Cetakan I. Yogyakarta: Gava Media.

Purnama, W., \& Daljono (2013). Pengaruh Ukuran Perusahaan, Rasio Leverage, Intensitas Modal, dan Likuiditas Perusahaan terhadap Konservatisme Perusahaan (Studi pada Perusahaan yang Belum Menggunakan IFRS). Diponegoro Journal of Accounting, 2(3), $1-11$.

Quljanah, M., Nuraina, E., \& Wijaya, A. L. (2017). Pengaruh Growth Opportunity dan Leverage terhadap Konservatisme Akuntansi (Studi Empiris Perusahaan Manufaktur yang Terdaftar di BEI). Forum Ilmiah Pendidikan Akuntansi, 5(1), 477-488.

Raharjo, R. S., \& Dewi, N. U. S. (2016). Pengaruh Ukuran Perusahaan, Rasio Leverage, dan Intensitas Modal terhadap Konservatisme Akuntansi Pasca Adopsi Penuh IFRS. 
Kolaborasi Riset Dosen dan Mahasiswa Sekolah Tinggi Ilmu Ekonomi Perbanas, 1(1), 112.

Rizkyka, Nurhayati, Fadilah. (2017). Pengaruh Risiko Litigasi dan Tingkat Kesulitan Keuangan terhadap Konservatisme Akuntansi. Prosiding Akuntansi Universitas Islam Bandung.

Ross, Westerfield, Jordan. (2010). Corporate Finance 8th ed. New York: McGraw-Hill.

Savitri, Enni. (2016). Konservatisme Akuntansi Cara Pengukuran, Tinjauan Empiris dan FaktorFaktor yang Mempengaruhinya. Yogyakarta: Pustaka Sahila Yogyakarta.

Sekaran, U., \& Bougie, R. (2016). Research methods for business: A skill-building approach. $7^{\text {th }}$ edition. Chicherster, West Sussex: John Willey \& Sons, Inc.

Sinarti, \& Mutihatunnisa, S. (2015). Pengaruh Ukuran Perusahaan, Rasio Leverage serta Intensitas Modal terhadap Penerapan Konservatisme Akuntansi pada Seluruh Perusahaan Sektor non Finansial yang Terdaftar di BEI tahun 2014. Jurnal Politeknik Negeri Batam, $1-6$.

Susanto, B., \& Ramadhani, T. (2016). Distributed Demand-Side Optimization in the Smart Grid. Jurnal Bisnis Dan Ekonomi (JBE), 23(2), 142-151.

Watts, Ross L. and Zimmerman, Jerold L. (1986). Positive Accounting Theory. Prentice-Hall Inc. 